\title{
SEBARAN LIMBAH CAIR INDUSTRI TEKSTIL DAN DAMPAKNYA DI BEBERAPA DESA KECAMATAN RANCAEKEK KABUPATEN BANDUNG
}

\author{
OUTSPREAD OF TEXTILE INDUSTRY WASTE WATER AND ITS IMPACT \\ TO A NUMBER OF VILLAGES IN RANCAEKEK DISTRICT, BANDUNG REGENCY \\ Wage Komarawidjaja \\ Pusat Teknologi Lingkungan -Badan Pengkajian dan Penerapan Teknologi \\ Gedung Geostech 820, Puspiptek Serpong 15314, Indonesia \\ Email : wage.komarawidjaja@bppt.go.id
}

\begin{abstract}
In Rancaekek, textile industry wastewater is expected to influence the environment of the villages such as Jelegong and Linggar. Therefore, this study aims to analyse the industrial pollution impact to the surrounding environmental. Water and soil analysis results showed water quality of the river and land in the rice fields around the textile industry contain inorganic matter (TOM) and heavy metals in high concentration. TOM content of Cikijing river water is indicated by the high concentration of $\mathrm{KMnO} 4859.1 \mathrm{mg} / \mathrm{I}$, while heavy metals in soil occur as a result of the accumulation process in which the concentration of $\mathrm{Cr}(8.56 \mathrm{mg} / \mathrm{I}), \mathrm{Pb}(9.06-16.64 \mathrm{mg} / \mathrm{I})$, As (8.4 to $13.2 \mathrm{mg} / \mathrm{I})$ and $\mathrm{Zn}(2.87$ to $92.69 \mathrm{mg} / \mathrm{I})$, on the otherhand the concentration of heavy metals in the Cikijing river are about $<0.005-0.07 \mathrm{mg} / \mathrm{l}$. Based on these studies, it is recommended to minimize the impact of pollution with compliance efforts on wastewater management regulations and applying the techniques of phytoremediation land.
\end{abstract}

Keywords: textile wastewater, potassium permanganate, heavy metals, wastewater treatment, phytoremediation

\begin{abstract}
ABSTRAK
Di Kecamatan Rancaekek terdapat industri tekstil yang limbah cairnya diduga mempengaruhi kondisi lingkungan desa-desa seperti Jelegong dan Linggar. Oleh karena itu, penelitian ini bertujuan mengkaji dampak pencemaran industri terhadap kondisi lingkungan hidup di sekitarnya. Hasil analisa air dan tanah menunjukkan air sungai dan lahan pertanian sawah di sekitar industri tekstil mengandung bahan organik dan logam berat dengan konsentrasi yang cukup tinggi. Kandungan bahan organik air Sungai Cikijing yang tinggi ditunjukkan oleh konsentrasi $\mathrm{KMnO}_{4}$ yang tinggi 859,1 $\mathrm{mg} / \mathrm{l}$, sedangkan pencemaran tanah oleh logam berat yang tinggi terjadi akibat proses akumulasi dimana konsentrasi $\operatorname{Cr}(8,56 \mathrm{mg} / \mathrm{l})$, Pb (9,06 - 16,64 mg/l), As (8,4-13,2 mg/l) dan Zn (2,87-92,69 mg/l), sementara konsentrasi logam berat dalam air Sungai Cikijing hanya berkisar antara $<0,005-0,07$ $\mathrm{mg} / \mathrm{l}$. Berdasarkan Penelitian tersebut, direkomendasikan upaya meminimalisir dampak pencemaran dengan upaya pentaatan terhadap regulasi pengelolaan limbah cair dan menerapkan teknik fitoremediasi lahan.
\end{abstract}

Kata kunci : limbah cair tekstil, kalium permanganat, logam berat, pengolahan limbah, fitoremediasi

\section{PENDAHULUAN}

\subsection{Latar Belakang}

Rancaekek pada Gambar-1 adalah kecamatan di Kabupaten Bandung bagian Timur yang sejak tahun 1980 telah berkembang menjadi alternatif kawasan industri. Wilayah ini sebelumnya merupakan kawasan pertanian lahan basah yaitu padi sawah yang merupakan komoditas unggulan terbesar di Jawa Barat ${ }^{1)}$. Namun, kota Kecamatan ini mengalami transformasi alih fungsi dari kawasan pertanian menjadi kawasan industri yang secara fisik ditandai oleh pertumbuhan bangunan pabrik dan semakin padatnya permukiman penduduk. 


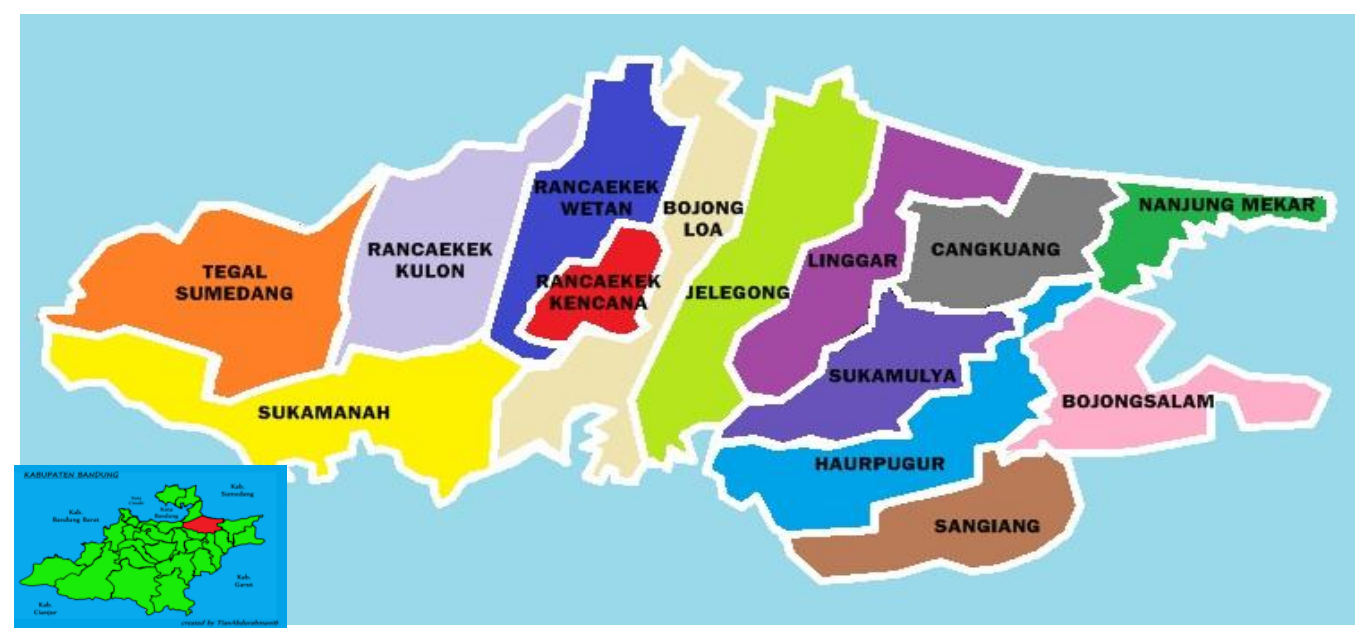

Sumber : BPS Kab. Bandung ${ }^{2)}$.

Gambar-1. Peta Administrasi Desa Jelegong dan Desa Linggar di Kec. Rancaekek Kab. Bandung.

Pertumbuhan industri tersebut dikuasai oleh sektor industri tekstil dan produk tekstil (TPT). Pertumbuhan industri ini, di satu sisi membantu program alokasi tenaga kerja, tetapi disisi lain dirasakan telah menurunkan kualitas lingkungan setempat, yang secara langsung dapat dirasakan dari indikator pencema seperti bau menyengat dan warna hitam pekat air limbah yang dibuang melalui Sungai Cikijing ${ }^{3)}$. Sementara Sungai Cikijing digunakan masyarakat untuk kebutuhan domestik seperti mandi dan cuci serta dimanfaatkan petani untuk mengairi sawah yang tersebar di sekitar wilayah Rancaekek, tetapi diduga, baik secara langsung maupun tidak langsung, sungai tersebut telah terkontaminasi oleh limbah cair proses industri yang termasuk didalamnya limbah penggunaan bahan pewarna tekstil.

Sungai Cikijing sebagai anak sungai Clkeruh mengalir dari utara ke selatan membelah wilayah Kecamatan Rancaekek dan akhirnya bermuara di Sungai Citarum. Adanya kontaminasi limbah yang terus menerus diterima oleh badan sungai Cikijing dalam waktu yang lama, dimana airnya dimanfaatkan masyarakat sebagai sumber air untuk mandi dan cuci serta untuk mengairi persawahan, sangat membahayakan kehidupan hayati dan membahayakan kesehatan mahkluk hidup termasuk manusia melalui proses pencemaran antropogenik ${ }^{3,4)}$.

Ada indikasi hampir ratusan hektar sawah di kawasan Rancaekek, khususnya di Desa Linggar, Babakan, Bojong Loa dan Jelegong tercemar logam berat dan bahan kimia beracun, yang berdampak terhadap penurunan kualitas dan produkstifitas padi sawah setempat ${ }^{1,5,6)}$.

\subsection{Tujuan}

Penelitian ini bertujuan untuk mendalami pengaruh dampak peneamaran limbah cair industri tekstil terhadap lingkungan hidup disekitarnya.

\section{BAHAN DAN METODE}

\subsection{Tempat Penelitian}

Penelitian ini dilaksanakan aliran Sungai Cikijing setelah melewati kawasan Industri Tekstil dan masuk kedalam wilayah Desa Linggar dan Jelegong, Kecamatan Rancaekek, Kabupaten Bandung.

\subsection{Parameter Kualitas Lingkungan yang Diukur}

Kualitas Lingkungan yang diukur meliputi parameter biologi dan kimia kualitas air dan tanah sepanjang aliran Sungai Cikijing di Desa Linggar dan Jelegong. Lokasi Pengambilan contoh air dan tanah, disajikan pada Gambar-2.

Mikroba lokal yang diperoleh dengan menumbuhkan pada media selektif, selanjutnya digunakan uji proses degradasi dari limbah industri tekstil yang masuk ke Sungai Cikijing. Selama proses degradasi berlangsung dilakukan pengukuran terhadap parameter derajat keasaman $(\mathrm{pH})$, total partikel terlarut (TDS), total partikel tersuspensi (TSS) dan kalium permanganat $\left(\mathrm{KMnO}_{4}\right)$. Skema alat proses degradasi sekala Laboratorium disajikan pada Gambar-3. 


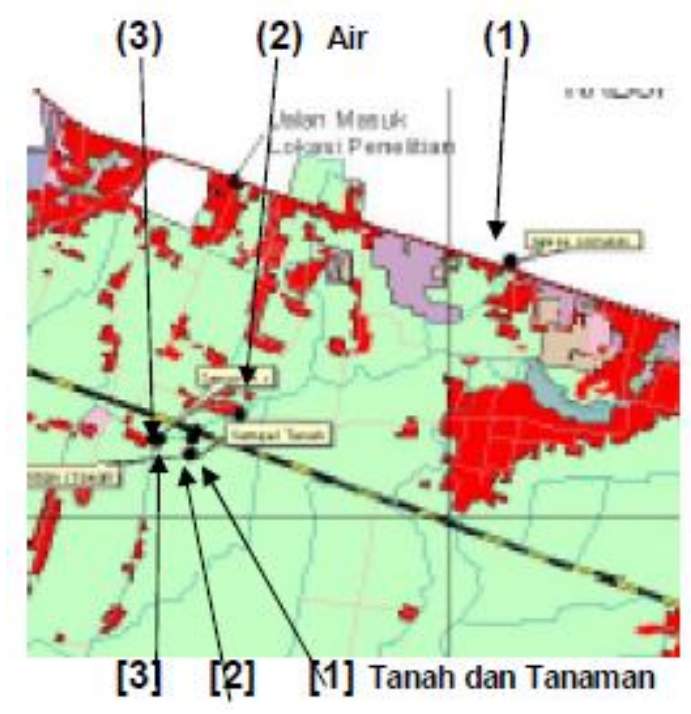

Gambar-2. Lokasi Stasiun Pengambilan Contoh Air (1 dst.) dan Tanah [1 1 dst.] Terkontaminasi Limbah Cair Tekstil,

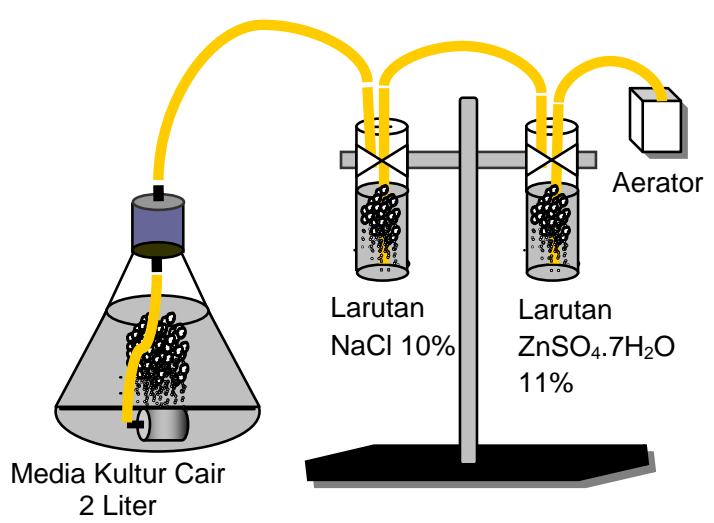

Gambar-3. Skema Proses Degradasi Limbah Cair Tekstil,

Contoh tanaman budidaya kangkung (Ipomea reptans) yang tumbuh disekitar lokasi pengambilan contoh untuk diukur kadar logam beratnya yaitu cadmium (Cd), khromium (Cr), plumbum $(\mathrm{Pb})$, arsen $(\mathrm{As})$ dan seng $(\mathrm{Zn})$.

Dari setiap lokasi pengambilan contoh air akan diukur kandungan parameter nitrit $\left(\mathrm{NO}_{2}\right)$, nitrat $\left(\mathrm{NO}_{3}\right)$, kalium permanganat $\left(\mathrm{KMnO}_{4}\right)$, Phenol dan logam berat yang mencakup $\mathrm{Cd}, \mathrm{Cr}$, $\mathrm{Pb}$, As dan Zn. Sedangkan parameter sampel tanah yang diukur adalah logam berat yang meliputi mencakup $\mathrm{Cd}, \mathrm{Cr}, \mathrm{Pb}$, As dan $\mathrm{Zn}$.

\section{HASIL DAN PEMBAHASAN}

\subsection{Uji Degradasi Limbah Cair Tekstil.}

Setelah dilakukan proses adaptasi isolat Mikroba terhadap limbah cair dari kawasan industri tekstil, selanjutnya mikroba digunakan dalam uji degradasi. Hasil uji degradasi limbah oleh mikroba terseabut tercermin dari hasil pengukuran beberapa parameter, sebagaimana disajikan pada Tabel-1.

Tabel-1. Hasil Uji Laboratorium Proses Degradasi Limbah Cair Industri Tekstil.

\begin{tabular}{ccccc}
\hline \multirow{2}{*}{ Hari ke } & \multicolumn{4}{c}{ Parameter $(\mathbf{m g} / \mathrm{l})$} \\
\cline { 2 - 5 } & $\mathrm{pH}$ & $\mathrm{TDS}$ & $\mathrm{TSS}$ & $\mathrm{KMnO}_{4}$ \\
\hline 1 & 7,2 & 1701 & 370,7 & 5017 \\
\hline 2 & 7,2 & 2120 & 347,6 & 4015 \\
\hline 3 & 8,05 & 2626 & 553 & 3156 \\
\hline 4 & 8,69 & 2563 & 379,7 & 2297 \\
\hline 5 & 8,72 & 2594 & 271,5 & 599,7 \\
\hline 6 & 8,77 & 2469 & 160,3 & 542,7 \\
\hline
\end{tabular}

Parameter yang diukur antara lain adalah $\mathrm{pH}$, TSS, TDS dan $\mathrm{KMnO}_{4}$. Parameter $\mathrm{pH}$ diukur sebagai kontrol lingkungan selama proses oksidasi biologi. Dari hasil pengukuran dapat dilihat bahwa nilai $\mathrm{pH}$ semakin tinggi, hari pertama dan kedua sekitar 7,2 kemudian mulai hari ke tiga dan selanjutnya mengalami kenaikan nilai $\mathrm{pH}$. Data derajat keasaman ini menunjukkan bahwa oksidasi biologi yang terjadi selama pengembangbiakan mikroba lebih cenderung ke suasana basa.

Untuk parameter bilangan permanganat $\mathrm{KMnO}_{4}$ berkisar antara 542,7 - 5017 mg/l, menunjukkan kecenderungan penurunan kosentrasi dari hari pertama sampai pada hari kelima dan hari selanjutnya terlihat setagnan. Hal ini dimungkinkan terjadinya pengurangan atau degredasi bahan organik yang di wakili oleh bilangan permanganat oleh mikroba yang ada di dalam reaktor. Atau dengan kata lain mikroba telah memanfaatkan bahan organik sebagai nutrien untuk kebutuhan perkembangbiakannya.

Apabila dilihat kelarutan dari reaktor tersebut yang di wakili oleh nilai TDS berkisar antara 1701 - $2469 \mathrm{mg} / \mathrm{l}$. Nilai tersebut memiliki kecenderungan peningkatan kosentrasi suspensi yang ada di reaktor terutama hari pertama sampai hari ketiga. Sedangkan untuk TSS 
berkisar antara 160.3 - $553 \mathrm{mg} / \mathrm{l}$. Peningkatan kosentrasi TSS ini diduga merupakan indikasi peningkatan kepadatan mikroba hasil perkembangbiakan dalam reaktor. Proses perubahan kosnentrasi bilangan permanganat,dan TSS dapat dilihat pada Gambar-4.

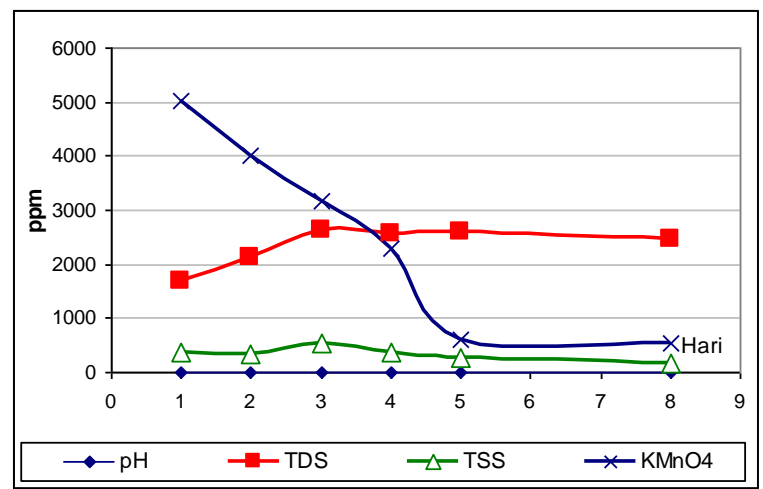

Gambar-4. Perubahan yang terjadi di reaktor untuk parameter $\mathrm{pH}$, TDS, TSS dan $\mathrm{KmnO} 4$

Dari gambaran konsentrasi bahan organik $\mathrm{KMnO}_{4}$ mengindikasikan bahwa limbah cair tekstil yang dialirkan ke saluran pembuangan masih mengandung organik yang tinggi, kemungkinan akibat IPAL yang dibangun tidak bekerja optimal. Hasil uji degradasi oleh mikroba terhadap sampel menunjukkan bahwa limbah tersebut dapat didegradasi oleh mikroba. Kemampuan degradasi mikroba tersebut memperkuat dugaan bahwa limbah dari kawasan indsutri terkstil belum diolah secara sempurna.

\subsection{Status Kualitas Air Sungai Cikijing}

Sebagaimana ditunjukkan pada peta Gambar-2, sampel air diambil di stasiun-1 yang mendekati sumber limbah cair di kawasan industri tekstil (hulu) sampai stasiun-3 (hilir) yang merupakan pertemuan antara saluran buangan dan lokasi dimana titik sampel tanah diambil.

Hasil analisis ini kemudian di bandingkan dengan baku mutu pertanian, yang tujuannya untuk melihat apakah dari segi sifat kimiawi telah melebihi baku mutu pertanian serta untuk melihat kelayakan dari sifat fisika-kimia dari limbah cair tekstil. Selanjutnya analisis kualias limbah cair dilakukan untuk mengetahui penyebaran limbah cair tekstil pada lahan budidaya dan penyerapan limbah oleh tanaman. Hasil analisa kualitas limbah cair dapat dilihat pada Tabel-2.

Menurut beberapa literatur bahwa industri tekstil biasanya menghasilkan bahan pencemar dari penggunaan zat pewarna tekstil yang digunakan. Zat pewarna tersebut merupakan senyawa azo ${ }^{7}$.

Untuk membuktikan adanya pencemaran di areal kajian tersebut, maka dilakukan pendekatan analisis parameter bilangan permanganat $\left(\mathrm{KMnO}_{4}\right)$ yang terkandung di saluran pembuangan limbah dari mulai hulu (dekat pabrik) sampai dengan hilir yaitu areal pesawahan ${ }^{8)}$. Bilangan permanganat ini mencerminkan konsentrasi organik yang terkandung di dalam limbah cair. $\mathrm{KMnO}_{4}$ biasanya digunakan sebagai oksidator penentuan konsumsi oksigen oleh bahan organik, yang lebih dikenal dengan istilah TOM (Total Organic Mater). Sebagai bahan perbandingan untuk melihat adanya degradasi atau pengurangan bahan pencemar selama dalam perjalanan dari hulu sampai ke hilir maka dilakukan analisis Fenol ${ }^{7}$.

Hasil analisa konsentrasi $\mathrm{KMnO}_{4}$ mulai dari hulu atau di saluran pembuangan industri di Stasiun-1 mempunyai kosentrasi $859.1 \mathrm{mg} / \mathrm{l}$, kandungan bilangan permanganat yang sama terdeteksi di hilir saluran (stasiun-3) sebesar $859.1 \mathrm{mg} / \mathrm{l}$. Bilangan permanganat tersebut menunjukkan bahwa konsentrasi limbah cair tekstil tidak mengalami perubahan sejak dari kawasan industri tekstil hingga di kawasan budidaya petanian yang berada di sebelah hilir kawasan industri tersebut, karena terbukti di area pesawahan yang airnya sudah mengalami pengendapan nilainya masih tinggi sekitar 649.6 $\mathrm{mg} / \mathrm{l}$. Sedangkan dari hasil analisa fenol diperoleh nilai yang tidak signifikan yaitu $<0.005$ $\mathrm{mg} / \mathrm{l}$ di semua stasiun pengamatan. Konsentrasi fenol ini mencerminkan bahwa sepanjang perjalanan limbah dari sumber (hulu) sampai ke hilir saluran dan areal pesawahan tidak terjadi degradasi zat pewarna azo ${ }^{7)}$.

Sedangkan untuk kandungan nitrogen dalam limbah cair di lihat dari kandungan nitrat dan nitrit menunjukan konsentrasi $<0.001 \mathrm{mg} / \mathrm{l}$ yang di temukan di saluran pembuangan limbah industri tekstil.

Kondisi ini masih dikatagorikan ke dalam kondisi toleran, karena masih di bawah $0.06 \mathrm{mg} / \mathrm{l}$ (Canadian Council of Resources and Enviromental Minister, 1987) ${ }^{9,10)}$. Di perairan itu sendiri Nitrit sekitar $0.001 \mathrm{mg} / \mathrm{l}$ dan jarang melebihi $1 \mathrm{mg} / \mathrm{l}$ (Sawyer dan McCarty, 1978) karena segera teroksidasi menjadi nitrat ${ }^{11)}$.

Sumber nitrit dapat berasal dari limbah industri atau domestik yang menggunakan garam-garam nitrit sebagai penghambat terjadinya proses korosi. Kadar nitrit melebihi $0.05 \mathrm{mg} / \mathrm{l}$ dapat bersifat toksik terhadap organisme perairan yang sensitif ${ }^{8)}$. 
Tabel-2. Hasil analisis sampel air Sungai Cikijing

\begin{tabular}{|c|c|c|c|c|c|c|c|c|c|c|}
\hline \multirow[t]{2}{*}{ Stasiun } & \multicolumn{2}{|c|}{ Nitrogen } & \multirow[t]{2}{*}{$\mathrm{KMnO}_{4}$} & \multirow[t]{2}{*}{$\mathrm{PhOH}$} & \multirow{2}{*}{$\begin{array}{c}\text { Lemak } \\
\& \\
\text { Minyak }\end{array}$} & \multicolumn{5}{|c|}{ Logam } \\
\hline & $\mathrm{NO}_{2}$ & $\mathrm{NO}_{3}$ & & & & $\mathrm{Cd}$ & $\mathrm{Cr}$ & $\mathrm{Pb}$ & As & $\mathrm{Zn}$ \\
\hline (1) 6 & $<0.001$ & $<0.02$ & 859.1 & $<0.005$ & 43.08 & $<0.005$ & 0.07 & $<0.05$ & 0.05 & 0.04 \\
\hline (2) 5 & $<0.001$ & $<0.02$ & 649.6 & $<0.005$ & 5.01 & $<0.005$ & $<0.02$ & $<0.05$ & 0.04 & $<0.005$ \\
\hline (3) 1 & $<0.001$ & $<0.02$ & 859.1 & $<0.005$ & 43,08 & - & $<0.02$ & $<0.05$ & 0.05 & $<0.005$ \\
\hline
\end{tabular}

Hasil pengukuran nitrat, kosentrasi yang terukur di stasiun-1,2 dan 3 adalah sebesar $<0.020 \mathrm{mg} / \mathrm{l}$, nilai kosentrasi nitrat di tiap stasiun pengamatan menunjukan nilai kosentrasi yang lebih besar dari perairan alami sehingga kemungkinan sudah terkontaminasi oleh faktor lain. Dilihat dari tingkat kesuburannya bisa digolongkan ketingkatan perairan oligotrofik dengan kadar nitrat berkisar antar $0-1 \mathrm{mg} / \mathrm{l}^{9}$.

Selanjutnya, hasil analisa kandungan logam berat air di stasiun-1, 2 dan 3 disajikan pada Tabel-2. Analisis yang dilakukan adalah logam $\mathrm{Cd}, \mathrm{Cr}, \mathrm{Pb}, \mathrm{As}$ dan
Zn. Hasil anailsis tehadap kandungan $\mathrm{Cd}$ (Kadmium) di air buangan limbah sekitar $<0.005 \mathrm{mg} / \mathrm{l}$, bila dilihat dari persyaratan air untuk pertanian masih di bawah bakumutu yaitu $0.01 \mathrm{mg} / \mathrm{l}^{12)}$.

Untuk konsentrasi Kromium (Cr) berkisar antara $<0.02-0.07 \mathrm{mg} / \mathrm{l}$, di stasiun2, dan 3 mempunyai kosentrasi $\mathrm{Cr}<0.02$ sedangkan di stasiun-1 kosentrasinya tinggi $0.07 \mathrm{mg} / \mathrm{l}$, akan tetapi kosentrasi ini juga masih di bawah bakumutu peruntukan pertanian artinya masih layak karena masih di bawah $1 \mathrm{mg} / \mathrm{l}^{12)}$.

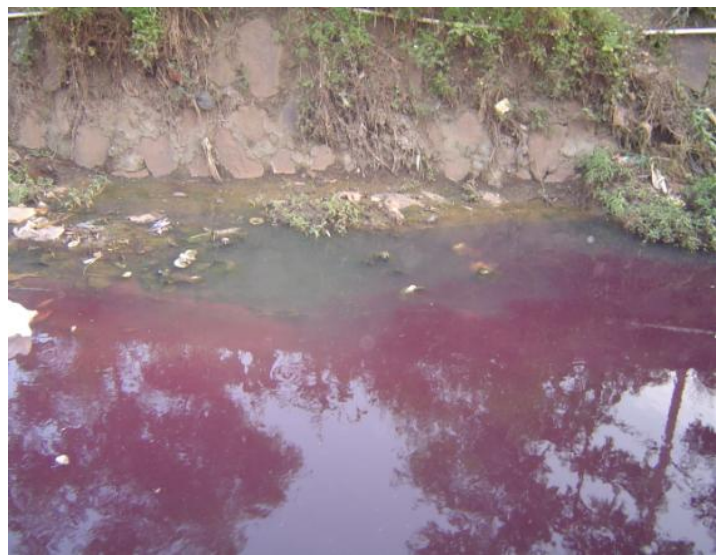

Gambar-5. Kondisi Sungai Sebagai Saluran Pembuangan Limbah Industri Tekstil

Begitu pula untuk logam berat jenis $\mathrm{Pb}$, As dan $\mathrm{Zn}$ nilai kosentrasi yang di peroleh masih dibawah standar yang diharuskan di pertanian atau masih layak dari segi kandungan logam berat di air.

Hasil analisis laboratorium diperoleh nilai kosentrasi $\mathrm{Pb}$ adalah $<0.005 \mathrm{mg} / \mathrm{l}$, As berkisar $0.02-0.05 \mathrm{mg} / \mathrm{l}$ dan $\mathrm{Zn}$ berkisar antara < 0.005-0.04 mg/l. Untuk Golongan D yang dipersyaratkan pertanian untuk $\mathrm{Pb} 0.2$ $\mathrm{mg} / \mathrm{l}$, As $1.0 \mathrm{mg} / \mathrm{l}$ dan Zn $0.2 \mathrm{mg} /{ }^{12)}$.

\subsection{Status Kualitas Tanah sekitar Sungai Cikijing}

Pengamatan logam berat dalam tanah dan tumbuhan (kangkung) dilakukan dengan asumsi bahwa logam berat akan terakumulasi di tanah dan tumbuhan pada daerah yang terkontaminasi limbah industri tekstil $^{13)}$. Hasil analisa laboratorium kandungan Logam berat dalam tanah, disajikan pada Tabel-3.

Dari hasil analisa labotatorium menunjukan bahwa kosentrasi Kadmium (Cd) di tanah hanya $<0.005 \mathrm{mg} / \mathrm{kg}$ akan tetapi akumulasi $\mathrm{Cd}$ dapat terlihat di tumbuhan sebanyak $12.06 \mathrm{mg} / \mathrm{kg}$. Nilai kosentrasi logam Kadmium di tanah sama dengan di air limbah hal ini menunjukan bahwa tanah tidak mengakumulasi logam berat jenis $\mathrm{Cd}$. 
Tabel-3. Hasil analisis Logam Berat Sampel Tanah di Rancaekek.

\begin{tabular}{cccccc}
\hline \multirow{2}{*}{ Stasiun } & \multicolumn{5}{c}{ Logam $(\mathrm{mg} / \mathrm{l})$} \\
\cline { 2 - 6 } & $\mathrm{Cd}$ & $\mathrm{Cr}$ & $\mathrm{Pb}$ & $\mathrm{As}$ & $\mathrm{Zn}$ \\
\hline 1 & $<0.005$ & $<0.02$ & 16.30 & 8.4 & 60.72 \\
\hline 2 & $<0.005$ & 8.54 & 16.64 & 8.8 & 92.69 \\
\hline 3 & $<0.005$ & $<0.02$ & 9.06 & 13.2 & 2.87 \\
\hline
\end{tabular}

Untuk jenis logam Kromium ( $\mathrm{Cr}$ ) di stasiun 1 dan 3 mempunyi kosentrasi $<0.02$ $\mathrm{mg} / \mathrm{l}$ sedangkan akumulasi logam berat dapat dilihat di stasiun pengamatan 2 sebesar $8.54 \mathrm{mg} / \mathrm{kg}$, kosentrasi akumulasi terbesar terdapat di tanaman kangkung sebesar $41,54 \mathrm{mg} / \mathrm{kg}$.

Hasil pengamatan terhadap kandungan logam berat jenis $\mathrm{Pb}$ dan $\mathrm{Zn}$ meperlihatkan karakter yang mirip yaitu di stasiun 1 dan 2 mempunyai nilai yang lebih besar dibandingkan stasiun 3 . Untuk $\mathrm{Pb}$ di stasiun 1 kosentrasinya $16.30-16.62 \mathrm{mg} / \mathrm{kg}$ dan di stasiun 3 adalah $9.06 \mathrm{mg} / \mathrm{kg}$, sedangkan kosentrasi $\mathrm{Zn}$ berkisar antara $2.82-92.72 \mathrm{mg} / \mathrm{kg}$.
Berdasarkan hasil analisa laboratorium, tanaman kangkung dari lokasi sampling, mengandung logam berat $\mathrm{Cd}$ (12,06 mg/kg), Cr (41,54 mg/kg), Pb $(69,42$ $\mathrm{mg} / \mathrm{kg})$, As (2,0 mg/kg) dan Zn (424 mg/kg), ternyata lebih besar dibanding yag terkandung dalam tanah tempat tanaman tersebut tumbuh sebagaimana disajikan pada Tabel-3. Sehingga dapat ditarik suatu kesimpulan bahwa akumulasi paling besar terdapat di tumbuhan, yang nilainya bisa beberapa kali bahkan ratusan kali dari kandungan logam berat di air dan tanah. Dengan akumulasi kandungan logam berat pada tanaman tersebut, sangat membahayakan kehidupan, karena bersifat toksik.

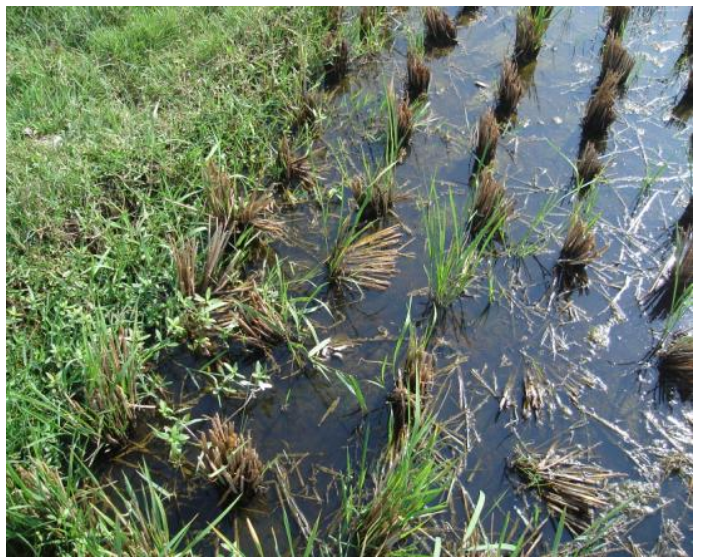

Gambar-6. Kondisi Lahan Persawahan yang tidak Produktif Akibat Kontaminasi dari Limbah Indusrti Tekstil

Satu dari masalah utama lingkungan yang dihadapi dunia saat ini adalah polusi pada tanah, air, dan udara yang terkontaminasi oleh bahan kimia beracun. Ada sebanyak 80 milyar pon polutan organik berbahaya diproduksi per tahunnya di USA dan hanya 10 persennya dari jumlah tersebut merupakan hidrokarbon yang dibuang secara aman. ${ }^{14)} \quad$ Senyawa berbahaya tertentu seperti polisiklik aromatik $(\mathrm{PAH})$, pentachlorofenol (PCP), polychlorinated bifenil (PCB), 1,1,1-trichloro2, 2-bis(4-chlorophenyl) ethane (DDT), benzene, toluene, ethylbenzene, dan xylene (BTEX), dan trinitrotoluene (TNT) adalah persisten dalam lingkungan dan diketahui mempunyai efek yang bersifat karsinogenik dan atau mutanogenik ${ }^{14)}$. Disamping itu, tidak kalah pentingnya dengan zat pewarna tekstil atau disebut juga Azo dyes yang sementara ini masih banyak digunakan dalam industri tekstil. ${ }^{13)}$

Hasil pengamatan dan analisa laboratorium mencatat bahwa lahan persawahan yang tadinya subur sudah tidak dapat ditanami lagi dengan padi, dan kemudian peruntukannya berubah menjadi lahan untuk perumahan. Ternayata hasil analisa sampel tanah menunjukkan, bahwa, selain lahan tercemar dengan logam berat, lahan juga tercemari oleh pewarna tekstil (Azo dyes) yang tinggi. 


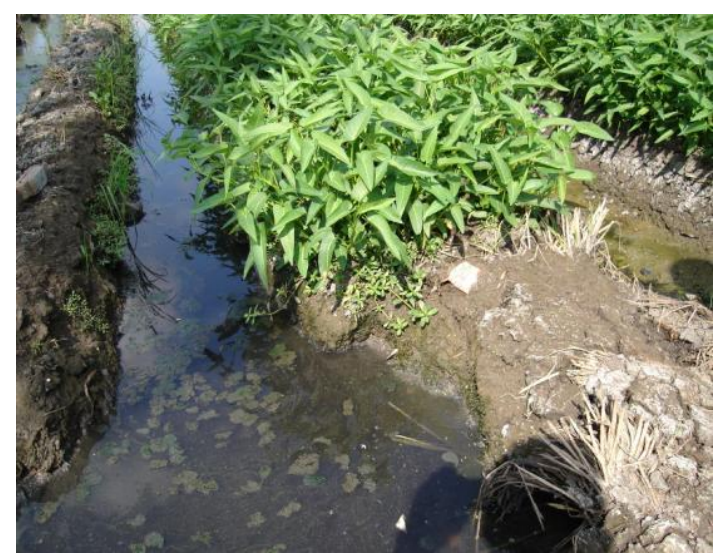

Gambar-7. Kondisi Tanaman Budidaya Kangkung (Ipomea reptans) yang Subur tetapi Mengandung Logam Berat yang Tinggi.

\subsection{Upaya Penanggulangan}

Berdasarkan pengamatan lapang (Gambar-5 dan Gambar-6) dan data analisa kualitas air dan tanah, bahwa perairan Sungai Cikijing setelah melewati kawasan industri tekstil masuk wilayah Desa Jelegong dan Linggar di Kecamatan Rancaekek, menunjukkan kualitas yang menurun. Dari gambaran konsentrasi bahan organik yang digambarkan oleh konsentrasi $\mathrm{KMnO}_{4}$ mengindikasikan bahwa limbah cair tekstil yang keluar dari saluran pembuangan dan masuk ke perairan Sungai Cikijing masih mengandung organik yang tinggi.

Sementara hasil uji degradasi oleh mikroba terhadap sampel limbah cair menunjukkan bahwa limbah tersebut dapat didegradasi oleh mikroba. Kemampuan degradasi mikroba tersebut memperkuat dugaan bahwa limbah dari kawasan indsutri terkstil belum diolah secara sempurna.

Beberapa alternatif untuk menanggulangi kondisi tersebut adalah dengan (1) memperkuat pentaatan aturan hukum lingkungan yang berlaku baik untuk pihak pemilik usaha industri tekstil dan pengelola kawasan, misalnya memperhatikan aturan peneglolaan dan pengolahan limbah seperti disebutkan dalam beberapa regulasi baik peraturan tingkat nasional maupun tingkat propinsi dan kabupaten/kota 12, 15, 16); (2) membangun instalasi pengolah limbah komunal sebagai alternatif pengolahan limbah ${ }^{1)}$; (3 ) sebelum dimanfaatkan sebagai sumber air budidaya tanaman pangan dan perikanan, terlebih dahulu dialirkan kedalam lahan sistem fitoremediasi. Upaya upaya tersebut diharapkan mampu menekan ekses pencemaran logam berat dan Azo dyes terhadap berbagai tingkat kehidupan ${ }^{1,13,17)}$.

\section{KESIMPULAN}

Dari uji degradasi limbah cair dapat disimpulkan, bahwa limbah cair yang dibuang ke sungai Cikijing pengolahannya belum sempurna, karna kandungan limbah organik stasiun-1 sampai stasiun-3 masih tinggi. Sumber bahan pencemar diduga berasal dari zat pewarna pakaian atau senyawa azo. Dari pengamatan hasil analisis limbah cair industri tekstil di Rancaekek Nitrogen (Nitrat dan Nitrit), Minyak dan Lemak serta logam berat $\mathrm{Cd}$, $\mathrm{Cr}, \mathrm{Pb}$, As dan $\mathrm{Zn}$, yang terukur masih relatif rendah. Sedangkan untuk logam berat dalam tanah menunjukkan terjadi akumulasi unsur $\mathrm{Cr}, \mathrm{Pb}, \mathrm{As}$ dan $\mathrm{Zn}$. Upaya penanggulangan pencemaran tersebut, sebaiknya mengkaji ulang upaya penegakkan hukum dan pembuatan instalasi fitoremediasi sebagai alternatif.

UCAPAN TERIMA KASIH. Ucapan terima kasih disampaikan kepada unsur Pimpinan BPLHD Propinsi Jawa Barat, yang telah memberikan arahan dalam melaksanakan penelitian, serta teman sejawat yang tidak dapat disebutkan satu persatu, yang telah banyak memberikan dukungan selama proses penelitian, penulisan, serta penyempurnaan hasil penelitian ini.

\section{DAFTAR PUSTAKA}

1. Ummi, N. S. D dan, L. S. Akliyah. 2016. Kajian Dampak Pencemaran Air Limbah Industri Terhadap Kondisi Fisik Lingkungan, Sosial-Ekonomi Masyarakat Kecamatan Rancaekek Kabupaten Bandung. (The Study of Industrial Water Pollution Impact toward The Physical Environment and Social-Economic at Rancaekek Residence Kabupaten Bandung). Prosiding Perencanaan Wilayah dan 
Kota Volume 2, No.2:167-175. ISSN: 2460-6480,

2. Anonimus. $2016 . \quad$ Kecamatan Rancaekek Dalam Angka 2016. BPS Kabupaten Bandung

3. Wijatmoko B dan Hariadi. 2008 . Studi Pola Sebaran Dan Kedalaman Polusi Air Tanah Berdasarkan Nilai Resistivitas Disekitar Saluran Pembuangan Air Limbah Industri Rancaekek Kabupaten Bandung. Jurnal Bionatura, Vol. 10, No. 1: 58 67.

http://balittanah.litbang.pertanian.go.id/i nd/dokumentasi/prosiding/25 Stno PR OOF-TK.pdf, diunduh 14 Nop. 2016

4. Sutono, S dan U. Kurinia. Identifikasi Kerusakan Lahan Sawah Di Rancaekek Kabupaten Bandung, Jawa Barat. Peneliti Badan Litbang Pertanian Pada Balai Penelitian Tanah, Jl. Tentara Pelajar 12, Cimanggu Bogor. http://balittanah.litbang.pertanian.go.id/i nd/dokumentasi/prosiding/25 Stno PR OOF-TK.pdf, diunduh 14 Nop. 2016

5. Anonimus. 2016. Konsekuensi Tersembunyi : Valuasi Kerugian Ekonomi Akibat Pencemaran Industri. www.melawanlimbah.org

6. Komarawidjaja, W. 200?. Status Makro Invertebrata pada Perairan DAS Ctarum Hulu yang Tercemar. Jurnal Teknologi Lingkungan (JTL) Vol 6, No.3 : 446-451. ISSN 1441-318X

7. Yuniati, 1997. Studi Kinetika Mikroorganisma pendegredasi Zat Warna Azo pada Kondisi Aerob. Thesis Magister pada Bidang khusus Rekayasa Pengelolaan Lingkungan. Program Studi Teknik Lingkungan. Program Pasca Sarjana Institut Teknologi Bandung.

8. Moore, J.W. 1991. Inorganic Contaminants of Surface Water. SpringVerlag. New York 334p

9. Efendi, H. 2003. Kualitas Air. Telaah Kualitas Air Bagi Pengelolaan Sumberdaya dan Lingkungan Perairan. Jurusan Manajemen Perairan. Fakultas Perikanan dan IImu Kelautan IPB

10. UNESCO/WHO/UNEP,1992). Water

Quality Assesments. Edited by Chapman and Hall Ltd. London. 585p

11. Sawyer, C. N. dan McCarty, P.L. 1978. Chemistery for Enviromental

Engineering. Third edition. McGraw-Hill Book Company. Tokyo. 532p

12. Anonimous, 2001. Peraturan Pemerintah No. 82 tahun 2001.
Tentang : Pengelolaan Kualitas Air dan Pengendalian Pencemaran Air.

13. Kurniasih, Y.A. 2008. Fitoremediasi Lahan Pertanian Tercemar Logam Berat Kadmium Dan Tembaga Dari Limbah Industri Tekstil. Skripsi. Departemen Teknik Pertanian Fakultas Teknologi Pertanian, Institut Pertanian Bogor. 60 hal. https://core.ac.uk/download/pdf/323489 87.pdf. Diunduh 14-11-2016

14. Reddy C. A. And Mathew, Z, 2001. Bioremediation potential of white rot fungi. In: Gadd GM (ed) Fungi in Bioremediation. Cambridge University Press, London, pp 52-78

15. Anonimous, $2014 . \quad$ Peraturan Pemerintah No. 5 tahun 2014. Tentang : Bakumutu Air Limbah.

16. Anonimus. 2008. Perda Kabupaten Bandung No.3 Tahun 2008 pasal 83 ayat tentang RTRW

17. Budhi Priyanto. Penerapan Uji Hayati Dengan Lemna Sp. Untuk Mengkaji Kualitas Air Sungai Yang Menerima Air Limbah Industri Tekstil Di Kabupaten Bandung. Balai Teknologi Lingkungan Badan Pengkajian dan Penerapan Teknologi Gedung 412, Kawasan PUSPIPTEK Serpong. http://download.portalgaruda.org/article. php?article $=62045 \&$ val $=4560$. Diunduh 14-11-2016 